\title{
THE LEVEL OF SOCIAL DISTANCE TOWARDS \\ VISUALLY IMPAIRED PERSONS REGARDING TO OCCUPATION IN BOSNIA AND HERZEGOVINA
}

\author{
Amela Teskeredžić ${ }^{1}$ \\ Dženana Radžo Alibegović \\ Senada Salkić
}

Faculty of Education and Rehabilitation Sciences, University of Tuzla

The Association of visually impaired citizens of Tuzla

Received: 16.02 .2016

UDC: $364.65-056.262(497.6)$

Accepted: 19.03.2016
Original scientific paper

316.644:364.65-056.262

\begin{abstract}
The aim of this study was to determine the level of social distance towards visually impaired people in relation to the occupation of respondents. The study included 361 adult respondents from the territory of Bosnia and Herzegovina, and who had no personal, not professional contact with persons with impaired vision. For the purpose of this study was used scale of social distance (Oullette-Kuntz, Burge, Brown, Arsenault, 2010), which is adapted in terms of required statements and opinions of respondents to visually impaired people, rather than toward people with intellectual disabilities. For statistical analyzes were used methods of descriptive statistics, and methods of analysis of variance (ANOVA). All results of the study were conducted at a significance level of 0.05 . The results indicate that there is no statistically significant difference in the opinions and level of social distance in relation to the occupation of respondents.
\end{abstract}

Key words: opinions, social distance, visually impaired people

\section{INTRODUCTION}

An opinion is a acquired disposition, acquired willingness to observe, think, emotionally react and act in a certain way. What will the reaction be depends on the individual experience that is gained through life. Although for all opinions their characteristic is their relative durability, the world around us is constantly changing and we are all, in our own way, sensitive to these changes. Trying to keep pace with time, to adapt to changes we change our opinions (Roth, 1998). Research has shown several common elements of opinions (Antonak and Livneh, according Favazza and Odom, 1997); Opinions are acquired through direct or indirect experience, interaction and events related to persons with disabilities. Studies show that children shape theiropinions towards people with disabilities from the fourth or fifth year of age (Gerber, 1977.; Jones and Sisk, 1970 ; according Favazza and Odom, 1997), and that these opinions are usually negative and rejecting (Yuker, 1988). Interventions in early childhood, to make the childrens affectance by changes smaler, may result in more positive opinions towards people with disabilities (Conant and Budoff, 1982 .; according Favazza and Odom, 1997).The opinions and attitudes of society towards persons with visual impairments are still not fully crystallized. When we talk about attitudes towards blind people a wide range of opinions about themcan be given. All these opinions are mostly stereotypical, and it is the irrational prejudices (Teskeredžić, 2005).

\footnotetext{
$\overline{{ }^{1} \text { Correspondence to: }}$

Amela Teskeredžić, Faculty of Education and Rehabilitation Sciences, University of Tuzla

Univerzitetska 1, 75 000, Tuzla, Bosnia and Herzegovina

Phone: +38761 195865

E-mail:amela.teskeredzic@untz.ba
} 
The concept of social distance is developed by E. Bogardus 1925, to investigate the opinions and prejudices against ethnic minorities (Šleznik, Šakaja, 2012). Social distance is a term often used to describe attitudes towards stigmatized groups and originally described by Bogardus as a degree of sympathy and understanding between individuals or groups (Oullette-Kuntz, Burge, Brown, Arsenault, 2010). The term social distance, for the first time, however, used the American sociologist R. E. Park at the beginning of the twentieth century. Social distance Park has defined as different levels of understanding and a sense of intimacy that occur in a variety of personal and wider social relations. Two decades after Park, Bogardus has formed the scale of social distance and thus allowed its measurement (Dinčić, 2013; Šleznik and Šakaja, 2012). The concept of social distance refers to the self (un) willingness of people to enter into interactions and activities with a person from the milieu which is being tested. Social distance can be low thus pointing to the admissibility of some of the population, or high, when talking about the tendency toward discrimination against certain groups (Nišević, Brkic., Golubovic, 2011). The goal of the research is to examine and determine the condition and level of social distance towards this population, and determine the difference in the average scores on a scale of social distance towards visually impaired people in relation to the occupation of respondents.

\section{METHODS OF WORK}

The study was conducted on a suitable sample of respondents. The study involved adult participants from almost all Cantons of the Federation of Bosnia and Herzegovina and Republika Srpska (with the exception of the Herzegovian-Neretvian Canton and Westherzegowinian Canton), who have no personal, and not professional contact with persons with impaired vision. The total number of respondents who participated in the study was 361 , but five respondents did not meet the part of the questionnaire, and their data were not used in further analysis. Therefore, the final number ofrespondents is 356. Dispersion expressed in the declaration of respondents in terms of interest, is reduced by constructing seven groups of answers: service industry, health care professionals, education professionals, administrative staff, unemployed, pensioners and pupils / students. From Table 1 it can be seen that the majority of the total samples consists of 131pupils / students (36.3\%), then the approximate number of respondents are 91servicesworkers $(25.2 \%)$, while the smallest number of samples are 10 pensioners (2.8 percent).

Table 1. Descriptive indicators for variable interest of subjects

\begin{tabular}{|c|c|c|c|}
\hline & & Frequency & Percent \\
\hline \multirow[t]{8}{*}{ Valid samples } & Service industry & 91 & 25.2 \\
\hline & Health care professionals & 18 & 5.0 \\
\hline & Education professionals & 17 & 4.7 \\
\hline & Administrative staff & 54 & 15.0 \\
\hline & Unemployed & 35 & 9.7 \\
\hline & Pensioners & 10 & 2.8 \\
\hline & Pupils / students & 131 & 36.3 \\
\hline & Total & 356 & 98.6 \\
\hline \multirow[t]{2}{*}{ Missing data } & & 5 & 1.4 \\
\hline & Total samples & 361 & 100.0 \\
\hline
\end{tabular}

The scaleof social distance for the purpose of this study was adapted in the sense that it is seeking submissions and opinions of respondents to visually impaired people, instead of to people with intellectual disabilities (Oullette-Kuntz, Burge, Brown, Arsenault, 2010). Respondents should mark on a five-point Likert scale the level of agreement (1-strongly agree, 2-agree, 3-I do not know, 4-disagree and 5-strongly disagree), with eight claims that represent certain situations that involve a level of intimacy, and through their answers respondents determine the level of social distance, and which would they prefer in such situations. 
The scale contains both positive and negative statements. Negative statements are contrary to encode during analysis. The total measure of social distance towards people with visual impairments is calculated by adding the answers on a scale. The starting point in determining the sensitivity of the questionnaire was the range of results. The lowest result obtained by testing is 8 , and the highest 40 points. As the arithmetic means are higher, the social distance (positive attitude) is smaller, and the opposite, as the arithmetic mean is lower, the greater the social distance (more negative) becomes, because the questionnaire is encrypted in this direction that the higher number of points carries less social distance, or better acceptance of people with visual impairments. Results are interpreted in the sense that higher scores indicating a lower social distance. Cronbach internal consistency coefficient obtained in this study was .85, indicating good reliability and internal approval of the scale for this sample.
For the statistical analysis were used methods of descriptive statistics, and to test the significance of differences, analysis of variance (ANOVA) was used. All results of the study were conducted at a significance level of 0.05 .

\section{RESULTS}

In order to start processing the data it was necessary to check whether the results of the scale of social distance is distributed according to the principles of the normal distribution. For this purpose, the KolmogorovSmirnov (K-Sz) test normality distribution is conducted. Results on the scale of social distance, range from 8 to 40 . The average score of respondents in terms of all the variables, which is the same as the average score of questionnaire, which in this case amounts to 33.05 with a standard deviation of 5.37 (Table 2).

Table 2. Minimum and maximum values, mean, standard deviation and test results are normal distribution (K-Sz) results for the total scale of social distance

\begin{tabular}{ccccccc}
\hline & Min & Max & $M$ & $S D$ & $K-S z$ & $p$ \\
\hline Social distance & 8.00 & 40.00 & 33.05 & 5.37 & 0.11 & .000 \\
\hline
\end{tabular}

Also, it shows that the average score on the scale of the total social distance deviates significantly from the normal distribution, and that it is negative asymmetrical, as it might be expected, since most respondents achieved higher scores on a scale of social distance. Results indicate less social distance of society towards people with visual impairments and can be considered that society exerts a positive attitude towards people with impaired vision. Distribution of the results on a scale is negatively asymetric, but the resulting index values asymmetry and flatness are in the ranges of acceptable values (asymmetry $<|1|$, flattening $<|3|$ ). It is believed that it is possible to use parametric statistics, if the distribution is relatively accurate (not bimodal or U-shaped), and if the sam- ples are large enough and of similar size (Petz, 1997). Since the data in this study satisfy these conditions, the statistical analysis,parametric procedureswere used.

To test the significance of differences in the total score on the scale of social distance toward people with impaired vision respectively to the respondentsoccupation, single-factor analysis of variancewas conducted. The assumption of homogeneity of variance was tested by Levene's test, and the result obtained justifies this assumption ( $\mathrm{W}=.575, \mathrm{df}=6, \mathrm{p}>.05$ ). Respondents are dividedby profession into seven groups: service industry; health care professionals; educational professionals; administrative staff; unemployed; pensioners and students / students (Table 3 ). 
Table 3. Mean, standard deviations and results of single-factor variance in the scale of social distance in relation to the occupation of respondents

\begin{tabular}{|c|c|c|c|c|c|}
\hline & $\mathrm{N}$ & M & SD & $\mathrm{F}$ & $p$ \\
\hline Service industry & 91 & 32.47 & 5.16 & & \\
\hline Health care professionals & 18 & 33.72 & 4.93 & & \\
\hline Education professionals & 17 & 33.23 & 4.43 & & \\
\hline Administrative staff & 54 & 34.90 & 4.40 & & \\
\hline Unemployed & 35 & 32.02 & 6.76 & & \\
\hline Pensioners & 10 & 32.90 & 5.19 & & \\
\hline Pupils / students & 131 & 33.00 & 5.46 & & \\
\hline Total & 356 & 33.10 & 5.33 & 1.546 & .162 \\
\hline
\end{tabular}

Results of this analysis of variance showed statistically significant differences in the level of social distance in relation to the level of qualification of the respondent do not exist, because the resulting value equals to $\mathrm{F}(6,349)=1.546$, and the significance equals to $\mathrm{p}=$ $.162(\mathrm{p}<0.05)$.

\section{DISCUSSION}

In the this study were examined the opinions of the public in general about the visually impaired, and that the condition and level of social distance toward this population was found. The difference in oppnions and level of social distance are determined in relation to the interest of a person covered by this study. Occupation along with education, and thus material position, one of the key indicators of the overall socio-economic status of the individual (Todorović, 2005), which is why this topic was taken into account in this study. Results on the scale of social distance are in the range between 8 and 40 . The average score of respondents was 33.05 with a standard deviation of 5,37 . The level of social distance towards people with impaired vision due to the occupation of respondents was examined using single-factor analysis of variance. Respondents were divided into seven groupsby their occupation. There was no statistically significant difference in the results of those groups: $\mathrm{F}(6,349)=1.546, \mathrm{p}=$ .162 . It should, however, be noted that the majority of the total samples consisted of pupils / students 131 $(36.3 \%)$, and theminority were 10 pensioners $(2.8 \%)$.It is important to note that the opinions and attitudes of society towards persons with impaired vision are not yet fully crystallized. Studies that have investigated the opinions of people with normal sight to visually impaired people, have shown that these opinions usually irrational prejudices that substantially impede the adaptation of visually impaired persons (Teskeredžić, 2005). Examination of opinions of wider social public and the level of social distane conducted alsoĆatić (2013), but to persons with physical disabilities. The sample consisted of 339 respondents of different gender, age, qualifications and occupations. The results showed that the majority of respondents have a positive attitude and a low level of social distance towards people with physical disabilities. However, there is a smaller percentage of respondents who expressed negative opinions and a high level of Social distance. Author emphasized that there were no significant differences in opinions towards people with physical disabilities in relation to age, gender, occupation and education.With increasment of intimacy to the given statements also increased the level of social distance among the respondents (Ćatić, 2013). Tomić, Sarajlić and Teskeredžić (2005) examined the opinions of students Faculty of Defectology in Tuzla on educational - educational integration of children with visual impairments, and the results they have obtained reflect mostly positive opinions of students of educational educational integration of these children. The degree of social distance that a person of normal vision shows to the blind can be predicted with very little success on the basis of knowledge of the opinions of people with normal vision to the emotional life of blind or on the basis of theiropinions to the limitations of blindness as physical damage (Teskeredžić, 2005). 
Surveys of opinions of people with normal sight to the blind conducted Stanimirović (according, Teskeredžić, 2005), on a sample of 150 people, from which are made 32 sub-samples of "specifically educated" people, who have worked in places that require work with blind people. It is stated that a person with normal sight exhibit greater social distance in situations where they are directly involved in close relations with the blind than in those situations where they are not in contact or in superficial contacts. It was found that people with lower education have distanced themselves from the blind, and those who had more contact with the blind have a lessersocial distance, and in addition to that, persons which have pronounced greater aggressive tendenciesdistance themselves more.

Walker (2008.) examined the opinions of consultants to visually impaired people. The survey included 300 respondents. The results showed that counsultants expressed negative attitudes towards people with impaired vision, and have little contact with them. Although the opinions of consultants to visually impaired people is extremely important, the author points out that this is a study, not on actual observation of behavior consultants in practice, and that caution should be exercised in generalizing the results. The views and opinions of experts who work with visually impaired people are very important. Jablan, Stanimirović, Maksimović and Srbović (2014.) examined the opinions of tiphlologist about children, that is about inclusive education in in Serbia and their awareness of inclusive education. The sample consisted of 43 tiphlologist. Analysis of the results showed that typhlologues expressed a positive opinion regarding the idea itself and the possibility of implementation of inclusive education. Basarov and Radojcik (2012.) examined the attitudes of students, who are directly connected with people who have visual impairments and those who indirectly related or have nothing to do with this people, in the Republic of Macedonia. Respondents answers differed depending on the degree of social distance contained in the question. 95\% respondents would socialize with people with visual impairments and would preparefor exams together. $93 \%$ of students does not mind after their study to work with these people. In view of the more sensitive issues, such as marriage with a blind person, the highest number of students was restrained. Very few students (4\% of special education teacher and $8 \%$ of computer scientists) which would get married to visually impaired people. In addition, $62 \%$ of special education teachers and $26 \%$ of computer scientists does not consider the problem to adopt a blind child. In our study are included subjects who had neither personal nor professional contact with persons with impaired vision.

Opinions towards people with disabilities are acquired through direct or indirect experience, interaction and events related to persons with disabilities. Interpersonal relationships require at least minimal interaction, and the success of these relationships depends on the degree of quality of established interaction (Teskeredžić, 2005.). Shiloh, Herut and Berkovitz (2011.) in their research concluded that visible disability is an important social and psychological factor in the formation of opinions, to form social distance towards people with disabilities. De Laat, Freriksen and Vervoed (2013.) examined the opinions of 200 Dutch high school students and 144 university students, according to people with disabilities. The results showed that the respondents had more positive attitudes toward the deaf, blind and paralyzed people, in respect to people with intellectual disabilities. They also found that the students had positive attitudes in general towards people with disabilities, which are linked with age, while in relation to gender and self-esteem in part influenced the results of opinions. Changing opinions of society towards people with disabilities requires the creation of conditions in which there will be interaction between people with and without disabilities (Najman-Hidžman, Leutar, Kancijan, 2008.).Eichinger andSur (1991.) conducted a study on two groups of students (control and experimental), on opinions towards people with disabilities. The experimental group had a course for 10 weeks, in which they received the basic results showed that students in the experimental group had a significant improvement in the opinions of the students in the control group. But what especially led to improvements were contacts with persons with disabilities, which broke the prejudice that existed with other groups of students. Kafka (2013.) conducted a study on 200 students of the University of Zagreb, where the results are consistent with hypotheses - that women and men who have had previous contact with a blind person, have a positive attitude about blind people and their social integration, while people more prone to social dominance and students of Engineering have more negative attitudes about blind people and their social integration. The results of quantitative research tend more positive attitudes about blind people and their social integration, but the author attributed this to the liberal attitudes of students towards minority groups. 
The researchs, which aimed to determine the opinions of the social environment to persons with impaired vision in terms of providing assistance to these people (Teskeredžić, 2007.), and to determine the opinions of the social environment for socializing of people with impaired vision (Teskeredžić, Bijedic, 2006.), have shown that if we give visually impaired people the chance to adapt to the social environment, and the social environment to them, we will have a society that will be fully utilized with all its resources, regardless of the degree and type of damage. Research carried out in neighboring Croatia (Najman-Hidžman, Leutar and Kancijan, 2008.) indicated a positive trend towards people with disabilities and the presence of prejudices in society, but also a desire for greater integration and removing physical barriers. Based on these findings, the authors concluded that it is possible to notice that the attitudes of citizens in Croatia is similar to the attitudes of citizens in the European Union. The criteria when respondents have no contact with visually impaired people is deliberately selected in order to determine whether such respondents have negative attitudes and greater social distance toward people with impaired vision. Nagata (2007.) points out that negative opinions are not, to people with disabilities, the most serious obstacles to the full participation and integration into society. The larger question is, "what is the current level of acceptance and recognition of people with disabilities in a society, and what kind of intervention is necessary to raise public awareness that will lead to positive change?"

\section{CONSLUSION}

There was no difference stated in the opinion and state of social distance in relation to the occupation of respondents. It may be noted that in addition to positive opinions and low social distance of the society to visually impaired people there are still many difficulties that these people face. The difficulties are related to education, employment, and accessibility of public places these people. These are, namely, the areas where the rights of visually impaired people, as well as other persons with disabilities, are still not respected enough. It is necessary to continue to work on the awareness of citizens of the visually impaired persons and their integration into society, with special emphasis put on socializing with visually impaired people from the earliest period of life. It is also important that state institutions take part in solving the difficulties that visually impaired people face, and to prepare a strategy for raising public awareness.

\section{REFERENCES}

Basarov, V., Dimitrova Radojcik, D. (2011). Students' attitudes towards people with visual impairments. Abstracts, "Special Education and Rehabilitation today", University of Belgrade, Faculty of Special Education and Rehabilitation, p. 81.

Ćatić, E. (2013). The views of society and the level of social distance towards people with physical disabilities. Master's thesis, Education and Rehabilitation Sciences, University of Tuzla.

Dinčić, J. (2013). Personality characteristics, social distance towards children with disabilities and special needs, and self-efficacy of teachers in inclusive practice. Master's thesis, Niš: Faculty of Philosophy, University of Nis.

Eichinger, J., Rizzo, T., Sirotnik, B. (1991). Changing Attmitudes Toward People with Disabilities. Teacher Education and Special Education: The Journal of the Teacher Education Division of the Council:14: 121-126.

Favazza,Paddy C., Odom, S. L. (1997). Promoting Positive Attitudes of Kindergarden-Age Children toward People with Disabilities. Journal Article Excerpt 63.

Jablan, B., Stanimirović, D., Maksimović, J., Srbović, J. (2014). What typhlologues in Serbia think about inclusive education and how are informed about this? Special Education and Rehabilitation, 13(1), 51-71.

Kafka, T.(2013). Integracija slijepih osoba u društvo. Diplomski rad. Filozofski fakultet u Zagrebu, Odsjek za sociologiju. Dostupno na: http://darhiv.ffzg.unizg.hr/3950/

Nagata, K. (2007). The measurement of the Hong Kong-based 'Baseline Survey of Students' Attitudes toward People with a Disability': cross-cultural validation in Lebanon. Int $J$ Rehabil Res.; 30(3):239-41. Dostupno na: http://www.ncbi. nlm.nih.gov/pubmed/17762771

Najman-Hidžman, E., Leutar, Z., Kancijan, S. (2008). The opinions of citizens towards people disabilities in Croatia in comparison with the European Union. Social ecology, 17(1), 71-93.

Nišević S., Brkić N., Golubović Š. (2011). Students opinions and social distance towards people with disabilities. Pedagogy, 66(1):126-133.

Oullette-Kuntz H., Burge P., Brown H. K., Arsenault E. (2010). Public Attitudes Towards Individuals with Inellectual Disabilities as Measured by the Concept of Social Distance. Journal of Applied Research in Intellectual Disabilities, 23(2): 132-142.

Petz, B. (1997). Basic statistical methods for nematematičare, Jastrebarsko: Slap Print, Zagreb.

Rot, N. (1998). Fundamentals of social psychology. Belgrade: Institute for textbooks and teaching aids.

Shiloh, S., Heruti, I., Berkovitz, T.(2011) Attitudes toward people with disabilities caused by illness or injury: beyond physical impairment.Int $J$ Rehabil Res. ;34(4):321-9. Dostupno na: http://www.ncbi.nlm.nih.gov/pubmed/22067548

Šleznik H., Šakaja, I.(2012). Spatial aspects of social distance towards Roma. Croatian Geographical Bulletin, 74(1): 91109.

Teskeredžić, A. (2005). The views of the social environment to visually impaired people. Master's thesis. Tuzla: Education and Rehabilitation Sciences, University of Tuzla. 
Teskeredžić, A., Bijedić, M. (2006). The state and prospects of relations of society towards people with visual impairments. Proceedings of the international and scientific conference "Rehabilitation of-state and prospects of children with disabilities and persons with disabilities", Rijeka: 304-314.

Teskeredić, A. (2007). The opinion of the social environment to assisting visually impaired people. Defectology. 13 (2): 209-216.

Todorović, D. (2005). The impact of ethnic and religious factors on Roms. Master's thesis. Niš: Faculty of Philosophy, University of Nis. Downloaded 29.06.2014. https://fedorani.ni.ac.rs/fedora/get/o:710/bdef.Content/get
Tomić, R., Sarajlić, DŽ., Teskeredžić, A. (2005). Opinions of a group of students Special Education Faculty in Tuzla on educational-educational integration. ,Our school“, $3: 147-155$.

Walker, C. L. (2008). Counselor Attitudes Toward People Who are Blind or Visually Impaired. A National Counselor Study, North Carolina State Uniresity.

Yuker, H.E. (1988). Attitudes Toward Persons with Disabilities. New York: Springer Publish Company. 